\title{
Pengaruh Lama Waktu Thawing Terhadap Kualitas Semen Beku Sapi Simmental Secara Mikroskopis
}

\author{
(The Influence of Long Thawing Time On The Quality of Simmental Frozen Cement \\ Microcopically) \\ Ririn Novita \\ Program Studi Peternakan Fakultas Pertanian Universitas Musi Rawas \\ Jl. Sultan Mahmud Badaruddin II Kel. Air Kuti Lubuklinggau Sumatera Selatan \\ Email Penulis Korespondensi : novitaririn91@yahoo.com
}

\begin{abstract}
ABSTRAK
Penelitian ini bertujuan untuk mengetahui pengaruh lama thawing terhadap kualitas semen beku Simmental. Meliputi dari motilitas masa Spermatozoa, konsentrasi Spermatozoa, Persentase Viabilitas Spermatozoa ,Persentase Abnormalisasi Spermatozoa dan Motilitas Individu yang dimana penelitian ini dilaksanakan di UPTD Balai Inseminasi Buatan (BIB) Sembawa, kabupaten Banyuasin, Provinsi Sumatera Selatan.Penelitian ini bersifat eksperimen dan dilakukan dengan menggunakan analisis sidik ragam rancangan acak lengkap (RAL) non-faktorial terdiri dari 6 taraf perlakuan dan 4 kali ulangan sehingga di dapat 24 unit percobaan. Adapun perlakuan yang digunakan adalah $S 1$ : 10 detik lama waktu thawing, S2 : 20 detik lama waktu thawing, S3 : 30 detik lama waktu thawing, S4 : 40 detik lama waktu thawing, S5 : 50 detik lama waktu thawing, S6: 60 detik lama waktu thawing. Hasil penelitian ini menggunakan lama waktu thawing 40 detik, dan berpengaruh sangat nyata terhadap viabilitas spermatozoa dan motilitas individu spermatozoa dan motilitas individu spermatozoa dan tidak berpengaruh nyata terhadap persentase abnormalitas spermatozoa.
\end{abstract}

Kata Kunci : Sapi simmental, thawing, spermatozoa

\section{ABSTRACT}

This study aims to determine the effect of thawing time on the quality of Simmental frozen semen. Includes spermatozoa mass motility, spermatozoa concentration, percentage of spermatozoa viability, percentage of spermatozoa abnormalities and spermatoza motility, where this research was conducted at the UPTD Institute for Artificial Insemination (BIB) Sembawa, Banyuasin district, South Sumatra Province. This research was experimental and was conducted using a non-factorial completely randomized design variance (CRD) analysis consisting of 6 treatment levels and 4 replications so that 24 experimental units were obtained. The treatments used are: S1: 10 seconds of Thawing time S2: 20 seconds of Thawing time S3: 30 seconds of Thawing S4: 40 seconds of Thawing time S5: 50 seconds of Thawing time S6: 60 seconds of Thawing time. The results of this study used a thawing time of 40 seconds, and had a very significant effect on the viability of spermatozoa and individual motility of spermatozoa 
and individual motility of spermatozoa and had no significant effect on the percentage of abnormal spermatozoa.

Keywords: simmental cow, thawing, spermatozoa

\section{PENDAHULUAN}

Ternak sapi potong di Indonesia membutuhkan perhatian khusus dalam kaitannya dengan upaya mempertahankan dan menunjang peningkatan populasi ternak.Kementerian pertanian republik Indonesia telah mencanangkan program swasembada daging sapi tahun 2014 untuk mendukung program ketahanan pangan dan program diversifikasi pangan nasional. Langkah - langkah strategis yang ditempuh dalam program swasembada tersebut salah satunya adalah dengan mengoptimalkan pelaksanaan inseminasi buatan (IB). Pelaksanaan kegiatan inseminasi buatan pada ternak merupakan salah satu upaya penerapan teknologi tepat guna yang merupakan pilihan utama untuk peningkatan populasi dan mutu genetik sapi. Keberhasilan inseminasi buatan pada ternak sapi telah mencapai 2.116.159 akseptor dengan kelahiran 1.333 .075 ekor pada tahun 2009. Inseminasi buatan adalah salah satu teknik yang dikembangkan untuk meningkatkan populasi ternak, dan inseminasi buatan juga mencegah penularan penyakit kelamin yang mungkin terjadi dalam perkawinan alami (Said et al, 2004).

Sapi Simmental merupakan sapi dwiguna (pedaging, dan pekerja). Melihat daya gunanya yang luas (dwiguna), pemerintah memperkirakan sapi ini cocok digunakan untuk memperbaiki mutu sapi di Indonesia.Sapi ini berukuran besar, pertumbuhan ototnya sangat baik dan tidak banyak penimbunan lemak dibawah kulit. Warna bulu pada umumnya krem kecoklatan hingga sedikit merah dan warna bulu pada muka putih. Demikian dari lutut kebawah dan ujung ekor warna buluh putih, tanduk tidak begitu besar, berat sapi betina mencapai $800 \mathrm{~kg}$ dan jantan $1150 \mathrm{~kg}$. Menurut Catur Windu Balai Inseminasi Buatan (BIB) Lembang, tahun 2008 pemerintah mengimpor sapi Simmental dari Australia pada tahun 1976 untuk pertama kalinya Sapi Simmental yang diimpor tersebut digunakan untuk keperluan grading up dan persilangan (Zakiah, 2009).

Upaya perbaikan mutu genetik ternak sapi Simmental daya lokal di sektor peternakan perlu dilakukan dengan tujuan untuk perbaikan kualitas produksi dan kelestarian genetik. Salah satu cara ke arah itu adalah melalui introduksi teknologi inseminasi buatandengan semen beku sapi Simmental. Namun seringkali terjadi gagal kebuntingan disebabkan rendahnya kualitas semen beku thawing. Indikator rendahnya kualitas semen beku thawing antara lain rendahnya motilitas massa ataupun individu, rendahnya angka viabilitas dan tingginya angka abnormalitas. Pengencer yang digunakan yaitu skim (buffer) kuning telur. Buffer berfungsi sebagai pengatur tekanan osmotik dan juga berfungsi menetralisir asam laktat yang dihasilkan dari sisa metabolisme, sehingga buffer diharapkan mempunyai kemampuan sebagai penyangga yang baik dengan toksisitas yang rendah dalam konsentrasi yang tinggi (Steinbach dan Foote, 1967 dalam Arifiantini et al., 2005).

Hal ini disebabkan salah satunya handling semen beku seperti thawing.Untuk mempertahankan kehidupan spermatozoa maka semen beku harus selalu disimpan dalam bejana atau konteiner berisi nitrogen cair yang bersuhu $-196^{\circ} \mathrm{C}$ dan terus dipertahankan pada suhu tersebut sampai waktu pakai. Semen beku yang dipakai, 
dikeluarkan dari konteiner dan dicairkan kembali supaya dapat disemprotkan kedalam saluran kelamin betina. Thawing membuat spermatozoa kembali hidup dan kembali ke temperatur tubuh sehingga thawing harus dilakukan secara hati-hati untuk menghindari kerusakan spermatozoa (Bearden et al., 2004).

Perbedaan kualitas semen beku thawing tersebut menunjukkan bahwalama waktu thawing yang berbeda memberikan pengaruh yang berbeda pula pada kualitas semen beku thawing sapi simmental. Oleh karena itu kemampuanmemformulasikan teknik thawing melalui perbedaan lama waktu thawing sangat menentukan kualitas spermatozoa semen beku pada proses thawing. Berdasarkan pemikiran inilah, maka perlu dilakukan penelitian untuk mengetahui pengaruh suhu dan lama thawing terhadap kualitas Semen beku sapi Simmental. Tujuan penelitian ini untuk mengetahui perbedaan lama thawing terhadap kualitas semen beku sapi Simmental.

\section{MATERI DAN METODE}

Penelitian ini dilaksanakan dari bulan Maret sampai dengan bulan Juli 2020. Penelitian ini dilaksanakan di UPTD Balai Inseminasi Buatan (BIB) Sembawa Kabupaten Banyuasin Provinsi Sumatera Selatan. Bahan yang digunakan dalam penelitian adalah: Semen beku sapi Simmental Jantan, Eosin, N2 Cair, NaCl, Aquades dan Air. Sedangkan alat yang digunakan dalam penelitian ini adalah Stopwatch/Timer, Gunting, water bath, Conteiner, Straw, Pipet ukur, Pinset, Mikroskop, Tv monitor, Objek glass, Cover glass, Mangkok, Tisu, Camber, Makro pipet, Kertas lebel, Mistar, Buku, dan Pena. Penelitian ini menggunakan metode eksperimental dengan Rancangan Acak Lengkap (RAL) terdiri dari 6 taraf perlakuan dengan 4 kali ulangan sehingga diperoleh 24 unit percobaan, setiap unit percobaan (tiap unit) diulang 4 kali.
Adapun taraf perlakuaan yang diujicobakan dalam penelitian ini adalah sebagai berikut: S1 thawing selama 10 detik, S2 selama 20 detik, S3 selama 30 detik, S4 selama 40 detik, S5 selama 50 detik, S6 selama 60 detik

\section{Persentase Viabilitas, Abnormalitas dan Motilitas Spermatozoa}

Straw diambil dari goblet dalam kontainer, kemudian straw dimasukkan kedalam waterbat dengan suhu $37 \circ \mathrm{C}$, dengan lama waktu thawing sesuai dengan perlakuan yang diamati yaitu: S1 thawing selama 10 detik, S2 selama 20 detik, S3 selama 30 detik, S4 selama 40 detik, S5 selama 50 detik, S6 selama 60 detik

Selanjutnya memotong ujung straw teteskan semen dalam objek glass, tutup dengan cover glass. Periksa dibawah mikroskop dengan skala 10 x $\quad 0,25$ (pemeriksaan motiitas spermatozoa).

Kemudian meteskan kembali semen sapi Simmental dan eosin kedalam objek glass dengan perbandingan1 : 3 (1 tetes semen sapi Simmental dan 3 tetes eosin). Kemudian kedua larutan dihomogenkan, objek glass kedua diambil dan disinggungkan ujungnya pada campuran eosin dan semen sapi Simmental lalu preparat ulas dibuat pada objek glass ketiga kemudian dikeringkan selama 5 - 10 menit.Periksa dibawah mikroskop dengan skala $10 \quad x \quad 0,25$ (pemeriksaan persentase hidup spermatozoa dan persentase abnormalitas spermatozoa) dengan menggunakan 4 titik sudut pandang berbentuk zikzak pada objek glass.

\section{Konsentrasi Spermatozoa}

Cara menghitung konsentrasi sperma menggunakan camber (semen beku) yaitu: Ambilsemen dalam straw dan pengencer (air) dengan perbandingan $1: 3$ tetes, campurkan $3 \% \mathrm{NaCl} 100 \%$ aquades menggunakan mikro pipet pada skala 0,5. Kemudian masukan kedalam camber, teliti dibawah mikroskop pada skala $10 \times 0,25$ dengan penghitungan 5 kamar pada camber. 
HASIL DAN PEMBAHASAN

Motilitas Massa spermatozoa Semen Beku pada Lama Wakt Thawing (\%)

Tabel 1. Motilitas Massa Semen Beku pada Lama Waktu Thawing

\begin{tabular}{|l|l|l|l|l|}
\hline \multirow{2}{*}{ Perlakuan } & \multicolumn{3}{|l|}{ Ulangan } \\
\cline { 2 - 5 } & 1 & 2 & 3 & 4 \\
\hline S1 & + & + & + & + \\
\hline S2 & + & + & + & + \\
\hline S3 & ++ & ++ & ++ & ++ \\
\hline S4 & ++ & ++ & ++ & ++ \\
\hline S5 & ++ & ++ & ++ & + \\
\hline S6 & + & ++ & ++ & + \\
\hline
\end{tabular}

Dari tabel diatas diketahui bahwa rata - rata motilitas massa yang memiliki nilai terkecil pada perlakuan S1 dan S2 yaitu + (lumayan), sedangkan nilai rata - rata perlakuan S3 dan S4 yaitu ++ (baik) kualitas motilitas maassa terbilang baik dengan lama waktu thawing 30 detik dan 40 detik.

Konsentrasi Spermatozoa Semen Beku Sapi Simmental pada Lama Waktu Thawing (\%).

Data perhitungan konsentrasi spermatozoa diperoleh seperti dibawah ini:

$=13,5+14+10+15+11,5 \times 10^{6}$

$=64 \times 10^{6}$

$=64.000 .000 \mathrm{spermatozoa} / \mathrm{ml}$

Viabilitas spermatozoa Semen Beku pada Lama Waktu Thawing (\%)

Dari hasil pengamatan viabilitas Individu Semen Beku pada Lama WaktuThawing dan hasil keragaman dapat di lihat pada lampiran 2, dengan hasil analisis ragam menunjukkan bahwa perlakuan berpengaruh sangat nyata terhadap kualitas semen beku sapi Simmental $(\mathrm{P}<0.01)$ yang dapat di lihat pada Gambar 1.

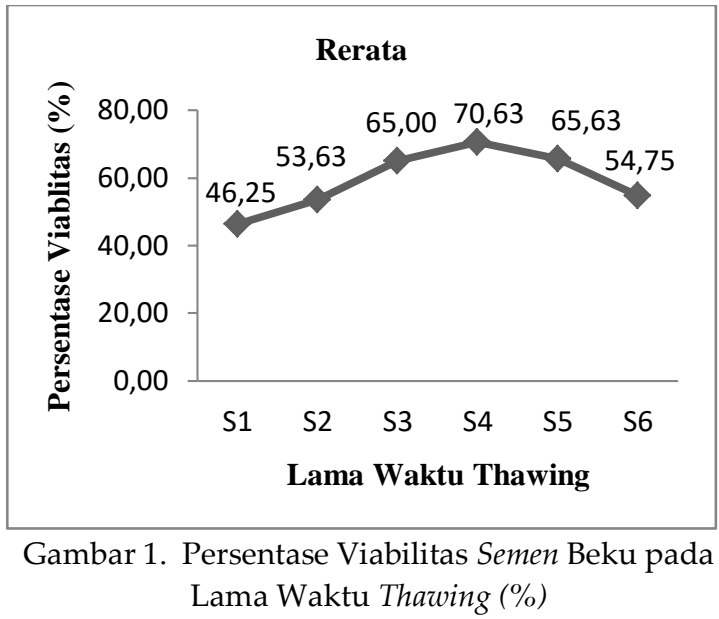

Rerata nilai terendah pada persentase viabilitas pada lama waktu thawing 10 detik yaitu perlakuan S1 sebesar $46.25 \%$, sedangkan rerata tertinggi pada lama waktu thawing 40 detik perlakuan S4 yaitu sebesar $70.63 \%$.

\section{Abnormalitas Spermatozoa Semen Beku pada Lama WaktuThawing (\%)}

Dari hasil pengamatan Abnormalitas Individu Semen Beku pada Lama Waktu Thawing dan hasil keragaman dapat di lihat pada lampiran 5, dengan hasil analisis ragam menunjukkan bahwa semua perlakuan berpengaruh tidak nyata terhadap kualitas semen beku sapi Simmental yang dapat di lihat pada Gambar 2.

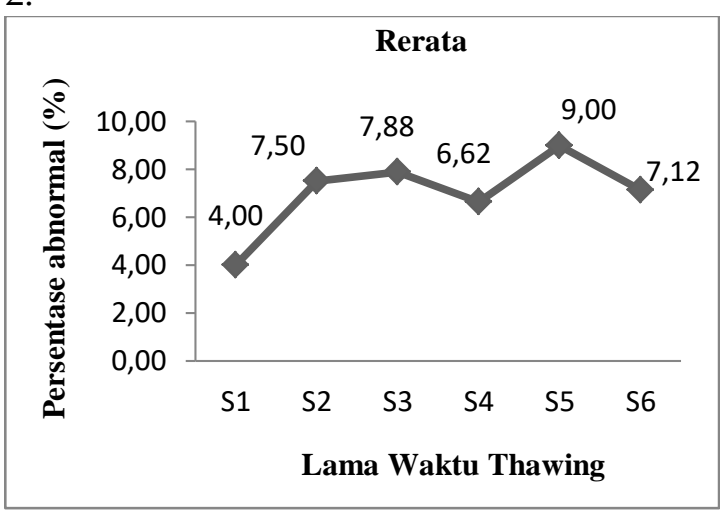

Gambar 2. Abnormalitas Spermatozoa Semen Beku pada Lama Waktu Thawing(\%)

Rerata nilai terendah (baik) pada persentase motilitas pada lama waktu thawing 10 detikyaitu perlakuan S1 sebesar $4.00 \%$, sedangkan rerata tertinggi (buruk) 
pada lama waktu thawing 50 detik perlakuan S5 yaitu sebesar $9.00 \%$.

\section{Motilitas Individu Spermatozoa Semen Beku pada Lama Waktu Thawing(\%)}

Dari hasil pengamatan Motilitas Individu Semen Beku pada Lama Waktu Thawing dan hasil analisis ragam menunjukkan bahwa perlakuan berpengaruh sangat nyata terhadap kualitas semen beku sapi Simmental $(\mathrm{P}<0.01)$ yang dapat di lihat pada Gambar 3.

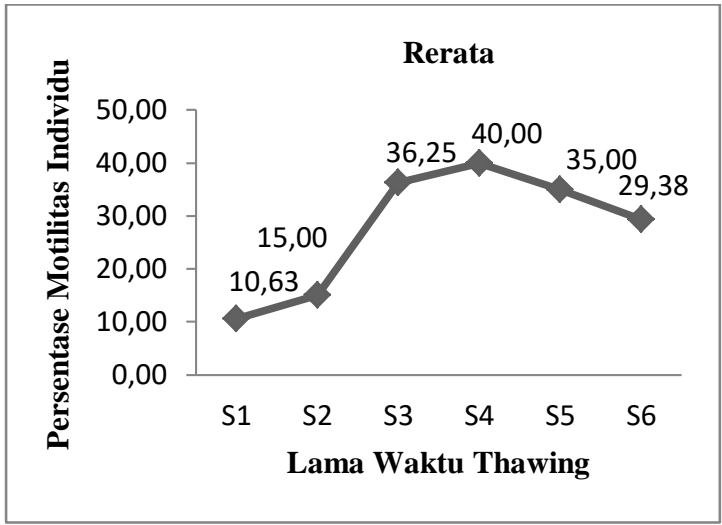

Gambar 3. Motilitas Individu Spermatozoa Semen Beku pada Lama Waktu Thawing(\%)

Rerata nilai terendah pada persentase motilitas pada lama waktu thawing 10 detikyaitu perlakuan S1 sebesar $10.63 \%$, sedangkan rerata tertinggi pada lama waktu thawing 40 detik perlakuan 54 yaitu sebesar $40 \%$.

\section{Pembahasan}

Salah satu metode untuk mengetahui kualitas spermatozoa sebelum dilakukan inseminasi buatan (IB) adalah dengan melaksanakan pemeriksaan kualitas spermatozoa secara mikroskopis. Data hasil perhitungan pemeriksaan yang dilakukan dalam penelitian ini meliputi konsentrasi spermatozoa, motilitas massa spermatozoa, viabilitas spermatozoa, abnormalitas spermatozoa dan motilitas individu setelah thawing. Semen beku sapi merupakan semen yang berasal dari pejantan sapi terpilih yang diencerkan sesuai prosedur proses produksi sehingga menjadi semen beku dan disimpan dalam rendaman nitrogen cair pada suhu $196^{\circ} \mathrm{C}$ pada kontainer.

Pada penelitian ini semen beku yang digunakan adalah semen beku dari sapi Simmental. Semen beku yang diproduksi memenuhi syarat yaitu semen beku sapi dikemas dalam bentuk straw dengan ukuran ministraw volume $0,25 \mathrm{ml}$ dengan jumlah sel spermatozoa minimal 25 juta (SNI, 2008). Penelitian ini dilakukan karena banyak pendapat mengenai lama waktu thawing yang dilakukan oleh inseminator dilapangan sebelum melakukan inseminasi buatan. Lama waktu thawing sangat berpengaruh besar terhadap keutuhan spermatozoa dalam semen, sebab selama ini banyak beberapa pendapat tentang lama waktu thawing pada semen beku yang akan digunakan dalam pelaksanaan inseminasi buatan maka dari itu untuk mengetahui kualitas spermatozoa yang paling optimal yang akan digunakan dalam pelaksanaan inseminasi buatan adalah dengan membandingkan penggunaan lama waktu thawing. Untuk menghindari bahaya cold shock pada straw beku dilakukan thawing selama 10 detik hingga 60 detik menggunakan air $37^{\circ} \mathrm{C}$ (Selk, 2002 dalam Affandhy dan Ratnawati, 2007)

\section{Motilitas Massa}

Dari hasil pengamatan secara mikroskopik semen beku selama penelitian, diperoleh rata-rata motilitas massa spermatozoa tertinggi adalah ++ hal ini menunjukkan bahwa gerakan sperma belum maksimal sedangkan nilai terkecil motilitas massa yaitu + (lumayan) karena semen buku belum mencair secara keseluruhan. Berdasarkan hasil pengamatan melalui mikroskop gerakan massa dari semen beku dinilai cukup, tidak terlihat gelombang melainkan gerakan-gerakan individual aktif progresif. Hal ini diduga adanya pengaruh lamanya dalam penyimpanan semen beku sapi simmental didalam conteiner.

Hasil penilaian gerakan masa adalah ++ (baik). Kondisi tersebut dalam keadaan baik, penilaian gerakan masa ++ (baik) 
menunjukkan bahwa spermatozoa dalam keadaan baik karena terlihat gelombanggelombang kecil, tipis, jarang, kurang jelas dan agak lamban. Hal ini sesuai dengan pendapat Susilawati, (2011) yang menyatakan bahwa Persentase motilitas sperma dinilai dari $0-100 \%$ pada 4 lapangan pandang sedangkan kecepatan sel bergerak antara 0-5.

\section{Konsentrasi Spermatozoa Semen Beku setelah Thawing $(\mathrm{ml})$}

Berdasarkan hasil penelitian lama waktu thawing terhadap kualitas semen beku sapi simmental di dapat nilai konsentasi spermatozoa yaitu $64 \times 10^{6}$ juta sperma/ml, menunjukkan bahwa tingkat konsentrasi semen beku masih terbilang bagus dan layak untuk digunakan inseminsi buatan (IB), hal ini sesuai pendapat Pineda, (2003) menyatakan bahwa konsentrasi permatozoa adalah $100 \mathrm{juta} / \mathrm{ml}$ atau 25 juta sperma/dosis straw.

Untuk meningkatkan konsentrasi maka hal yang harus diperhatikan adalah frekuensi ejakulasi. Frekuensi ejakulasi di Balai Inseminasi Buatan (BIB) Sembawa dilakukan satu kali seminggu tentunya frekuensi ejakulasi mempengaruhi konsentrasi spermatozoa.Hal ini sesuai dengan pendapat (Ismaya, 2014), pejantan yang sering dipakai dengan frekuensi yang tinggi dapat menyebabkan menurunya libido, volume spema, dan konsentrasi sperma.Konsentrasi spermatozoa dipengaruhi oleh perkembangan seksual dan kedewasaan sapi jantan sesuai kualitas makanan yang diberikan dan pengaruh kesehatan reproduksi.Oleh sebab itu manajemen dalam pemeliharaan bull, pakan, frekuensi ejakulasi hingga processing spema harus teratur agar konsentrasi semen beku dapat optimal.

\section{Viabilitas Spermatozoa Semen Beku setelah Thawing (\%)}

Hasil analisis ragam menunjukkan lama waktu thawing memberikan pengaruh yang sangat nyata $(\mathrm{P}<0,01)$ terhadap viabilitas spermatozoa semen beku. Hal ini di sebabkan karena lama waktu thawing dapat memberikan pengaruh terhadap pemeriksaan kualitas persentase viabilitas spermatozoa yang nantinya akan digunakan untuk inseminasi buatan pada ternak sapi Simmental untuk layak di gunakan atau tidak layak di gunakan. Pada penelitian ini menunjukkan persentase viabilitas terbaik yaitu pada perlakuan S4 dengan lama waktu thawing 40 detik sebesar $70.63 \%$, hal ini menunjukkan bahwa semen telah mencair secara keseluruhan sedangkan persentase motilitas terendah yaitu pada perlakuan S1 dengan lama waktu thawing 10 detik sebesar $46.25 \%$, karena semen beku belum mencair secara keseluruhan.

Kondisi ini disebabkan perlakuan S4 dengan lama waktu thawing 40 detik belum menyebabkan terjadinya tekanan osmotik secara ekstrim pada membran spermatozoa, sehingga permeabilitas membran utuh dan tidak terganggu, ini menjamin fluiditas dan keseimbangan homeostatis membrane sel karena pertukaran senyawa senyawa berlangsung secara normal. Semen dapat melewati masa kritisnya dengan cepat, karena hampir sama dengan temperatur tubuh hewan dan simulasilingkungan in vivo.

Semakin lama waktu thawing maka akan terjadi penurunan pada persentase viabilitas semen beku sapi Simmental. Dimana viabilitas tertinggi yaitu pada lama waktu thawing 40 detik sebesar $70.63 \%$ dan menurun menjadi $65.63 \%$ dengan lama thawing 50 detik. Lama yang tidak sesuai mengakibatkan membran spermatozoa mengalami kerusakan sebagai akibat cekaman panas dan kontak dengan oksigen. Membran spermatozoa yang tersusun dari fosfolipid mengalami reduksi karena timbulnya asam lemak dari proses peroksidasi sel. Hilangnya viabilitas sperma tidak bisa dihindari karena selama pengolahan semen, sperma mengalami perubahan kondisi lingkungan yang sangat ekstrim. Hal ini diperkuat oleh pendapat Anwar et al. (2014) yang menyatakan bahwa 
spermatozoa akan bekerja aktif dalam kegiatan biomolekul kimia metabolisme substrat yang diperlukan untuk pergerakan sehingga hasil akhir dari metabolisme berupa peningkatan asam laktat, tingginya asam laktat akan menurunkan $\mathrm{PH}$ pengencer yang akan menyebabkan toksin bagi kehidupan spermatozoa.

Kerusakan membran spermatozoa disebabkan karena selama proses thawing terbentuk radikal bebas metabolit oksigen yang bersifat toksik pada tingkatan yang rendah di dalam sel spermatozoa bersamaan dengan suplai oksigen yang terbatas, bersamaan pula dengan produksi radikal bebas pada pemulihan oksigen yang dipasok ke sel. Hal ini menimbulkan spekulasi bahwa peningkatan mendadak dalam pemanfaatan oksigen oleh spermatozoa menyebabkan peningkatan produksi radikal bebas, sehingga terjadi peningkatan lipidperoxidasi sebagi faktor penyebab kerusakan membran spermatozoa, hal ini sesuai dengan pendapat Witarsa, (2001) menyatakan bahwa semakin lama waktu thawing maka tingkat kematian spermatozoa akan meningkat.

\section{Abnormalitas Spermatozoa Semen Beku setelah Thawing (\%)}

Hasil analisis ragam menunjukkan lama waktu thawing yaitu berpengaruh tidak nyata terhadap abnormalitas spermatozoa semen beku. Hal ini di sebabkan karena lama waktu thawingtidak pengaruhterhadap pemeriksaan kualitas persentase abnormalitas spermatozoa yang nantinya akan digunakan untuk inseminasi buatan pada ternak sapi Simmentaluntuk layak atau tidak layak di gunakan. Pada penelitian ini menunjukkan persentase abnormalitas terbaik yaitu pada perlakuan S1 dengan lama waktu thawing 10 detik sebesar $4.00 \%$, sedangkan persentase abnormalitas terburuk yaitu pada perlakuan S5 dengan lama waktu thawing 50 detik sebesar $9.00 \%$ pada semen beku sapi Simmental.
Hal ini diduga semakin lama durasi thawing dan perlakuan bisa menyebabkan stres untuk spermatozoa tersebut, sehingga spermatozoa tidak mampu melewati masa kritis selama thawing karena panjangnya lama waktu thawing. Abnormalitas tertinggi dalam penelitian ini menunjukkan rataan pada perlakuan S5 yaitu $9.00 \%$ sehingga masih dapat dipergunakan untuk keperluan inseminasi buatan. Hal ini sesuai dengan pernyataaan BSN (2005) menyatakan bahwa Standar Nasional Indonesia mensyaratkan bahwa semen sapi memiliki morfologi abnormalitas baik primer maupun sekunder $20 \%$. Abnormalitas spermatozoa lebih dari $20 \%$ menunjukkan adanya infertilitas atau ketidaksuburan, abnormalitas spermatozoa lebih dari $20 \%$ tidak dapat digunakan untukinseminasi buatan.

\section{Motilitas Individu Semen Beku setelah Thawing (\%)}

Hasil analisis ragam menunjukkan lama waktu thawing memberikan pengaruh yang sangat nyata $(\mathrm{P}<0,01)$ terhadap motilitas ndividu spermatozoa semen beku. Hal ini di sebabkan karena lama waktu thawing dapat memberikan pengaruh sangat nyata terhadap pemeriksaan kualitas persentase motilitas individu spermatozoa yang nantinya akan digunakan untuk inseminasi buatan pada ternak sapi Simmentaluntuk layak di gunakan atau tidak layak di gunakan. Pada penelitian ini menunjukkan persentase motilitas terbaik yaitu pada perlakuan S4 dengan lama waktu thawing 40 detik sebesar 40,00 \%, hal ini menunjukkan semen beku telah mencair secara keseluruhan sedangkan persentase motilitas terendah yaitu pada perlakuan S1 dengan lama waktu thawing 10 detik sebesar $10.63 \%$, dikarenakan semen beku belum mencair secara keseluruhan.

Lama waktu thawing 40 detik memberikan angka persentase motilitas individu sebesar $40 \%$ Kondisi ini disebabkan karena pada perlakuan S4 suhu thawing sesuai dengan temperatur ideal bagi aktivitas motilitas spermatozoa.Lama waktu 
thawing yang terlalu panjang akan mengalami penurunan daya motilitas individu, pada perlakuan S5 dan S6 pada Lama waktu thawing 50 dan 60 detik sebesar $35.00 \%$ dan $29.38 \%$ menunjukan bahwa lamanya durasi thawing mengalami penurunan daya gerak spermatozoa. Hal ini sesuai dengan pendapat Rodriguez et a.l. (2005) menyatakan bahwa thawing pada semen beku sapi hingga 60 detik menyebabkan terjadinya beberapa kerusakan pada membran spermatozoa.

\section{KESIMPULAN}

Berdasarkan hasil dan pembahasan, dapat disimpulkan bahwa Lama waktu thawing semen beku Sapi Simmental berpengaruh terhadap motilitas individu dan persentase hidup sperma. Lama waktu thawing 40 detik pada perlakuan S4 memberikan pengaruh yang baik terhadap kualitas semen beku Sapi Simmental.

\section{DAFTAR PUSTAKA}

Affandhy, L. dan D. Ratnawati. 2007. Pengaruh Penggunaan Rak Straw Selama Equilibrasi terhadap Kualitas Semen Beku Sapi Peranakan Ongole. Loka Penelitian Sapi Potong. Pasuruan

Anwar, Y. S. Ondho dan D. Samsudewa. 2014.Pengaruh Pengencer Ekstrak Air Tebu dengan Penambahan Kuning Telur terhadap Kualitas Spermatozoa Sapi Bali. Universitas Diponegoro. Semarang.

Arifiantini, L., T. L. Yusuf, Dan Yanti D. 2005. Kaji Banding Kualitas Semen Beku Sapi Friesian Holstein Menggunakan Pengencer Dari Berbagai Balai Inseminasi Buatan di Indonesia. Animal Production 7(3): 168-176

Bearden, H. J., Fuquay, F. dan Willard, S.T. 2004. Applied Animal Reproduction, 6th edition, Pearson Prentice Hallm, New Jersey. USA
Badan Standar Nasional (BSN). 2005. Semen Beku Sapi. Badan Standarisasi Nasional. Standar Nasional (SNI) 014869.1-2005. BSN. Jakarta

Badan Standarisasi Nasional (BSN). 2008. Semen Beku-Bagian 1: Sapi (SNI 4869.1:2008). Jakarta.

Ismaya. 2014. Bioteknologi Inseminasi Buatan pada Sapi dan Kerbau. University Gajahmada. Yogyakarta

Pineda MH. 2003. Male Reproductive System. In Veterinary Endocrinology and Reproduction. $\quad 5^{\text {th }} \quad$ Edition. Edited by Pineda MH.And Dooley MP. Ames Blackwell Publishing.

Rodriguez, F. A-Almeida, M., Cuadras, A., Anchondo, S., Romo-Garcia, B. E., Sanchez, J. A., Jimenez, A. D., Alarcon-Rojo. 2005. Heparin Level Effect on Sperm Capacitation of Fresh an Frozen-Thawed Bovine Semen. Proceedings Vol. 56. American Society of Animal Science. Mexyco City.

Said, S., E.M. Kaiin, F. Afiati, M. Gunawan Dan B. Tappa. 2004. Perbaikan Teknik Pembekuan : Pengaruh Ketinggian Straw dan Penggunaan Rak Dinamis. Pros. Seminar Nasional. Teknologi Peternakan dan Veteriner. Bogor.

Susilawati. 2011. Spermatology. Universitas Brawijaya Press. Malang.

Witarsa, A. 2001. Evaluasi Semen dalam : Pelatihan Petugas Teknis Desentralisasi Balai Insemnasi Buatan Lembang, Ditjen Bina Produksi Peternakan. Jawa Barat.

Zakiah, Fitri. 2009. Penggunan Air Kelapa sebagai Penyeimbang Fruktosa dalam Pengencer terhadap Kualitas Sperma Sapi Simmental. USU Repository. 